the Cataract Construction Company's canal, and pass it after use into the tunnels belonging to this Company. The turbines drive a vertical shaft which, at the surface of the ground, is geared by bevel wheels to the main shaft, on which are the pulp grinders. This is the only case likely to occur where the power is used directly. In all other cases it is likely to be transmitted electrically. The first electrical application is to the works of the Pittsburgh Reduction Company for the manufacture of aluminium. The Niagara Falls Power Company has undertaken to supply them with continuous current at 160 volts to the extent of 7000 horse-power. The first 1500 horse-power is now being put in. In order to do this, Prof. Forbes has arranged to carry the alternating current by two circuits in two phases. This is the character of current generated by the dynamos. At the works, 2500 feet from the powerhouse, the current is to be transformed from 2000 volts to I 5 volts alternating. It is then passed through three of the commutating machines, like those shown by Schuckert and others at the Frankfort Exhibition of IS9I. These are continuous current machines, each with four rings attached to certain bars of the commutator. The alternating current is passed to these rings by brushes; the armature revolves synchronously with the generator in the power-house and with the turbine. The other brushes, which rub on the commutator, give off continous current to the aluminium baths at 160 volts, thu E.M.F. being (in normal conditions) raised in its change form alternating to continuous current in the ratio of $\sqrt{2}:$ I. A shunt direct current with variable resistance in the circuit excites the field magnets. It is found that the electromotive force of the direct current can thus be regulated. The explanation of this remarkable fact has been worked out by Mr. Steinmetz. The whole of this plant, transformers, commutating machines, and switchboard was tendered for by different firms, and the bid of the General Electric Company has been accepted ; 33 per cent. of spare plant is held in reserve. The dynamos and power-house switch-board, on the other hand, are in the hands of the Westinghouse Company. It is expected that both types of machinery will be in operation in the course of a few months.

The patent for Prof. Forbes' construction of dynamo, which is being built, has been just allowed by the United States Patent Office. One object to be attained was to have a fixed armature, so that the armature might be wound so as to give a very high E.MI.F. without being subjected to the enormous centrifugal forces of the revolving part. Another object was to attain a maximum fly-wheel effect. with a minimum weight. The revolving parts of the turbine and dynamo, and the vertical shaft connecting them, are all supported hydraulically by means of a piston in the turbine. The supporting power of this piston limited the weight of the revolving part of the dynamo to So,ooolbs. The governor of the turbine demanded (to fulfil the required conditions of regulation) a momentum equal to that of $1,100,000,000$ lbs., moving at the rate of I foot per second.

Both of these objects are attained by Prof. Forbes' construction, which consists in making the armature fixed and ring-shaped, with a space inside for getting at the bearings, and in making the fields of a bell-shape, the poles being on the inside of a nickel steel ring, which is supported by the top piece or cover, which in its turn is rigidly fixed to the vertical axis. This novel construction gives all the fly-wheel effect required without making the weight too great. Every design which had been made previously required the addition of a flywheel costing at least $£$ Soo or $£$ rooo. The construction for which Prof. Forbes' patent has now been granted has also the great merit that the magnetic pull between the armature and the fields tends to diminish the breaking strain of centrifugal force on the revolving part to a very No. 1279 , voL. 50] sensible amount. When the revolving part is inside the magnetic pull assists centrifugal force in its destructive effect.

\section{THE EPPING FOREST CONTROVERSY.}

THE meeting of the Essex Field Club, which, as we announced last week, had been convened for the inspection of the thinned districts of Epping Forest, was in every way a remarkable gathering. Nearly 150 members and visitors assembled in Monk's Wood, among them, in addition to the conductors and officers of the Club, being Sir John Lubbock, Mr. J. Bryce, MI.P., Chancellor of the Duchy of Lancaster, Prof. Boulger, Prof. WV. R. Fisher, Dr. Church, Mr. Arthur Lister, Mr. Andrew Johnston (chairman of the Essex County Council), Mr. David Howard, Mr. Salmon (chairman of the Epping Forest Committee), Sir Frederick Young, Mr. Bernard Gibson, and others interested in the question of the Forest management. A thorough examination of Monk's Wood was made, Mr. E. N. Buxton giving a detailed explanation of the policy which the Conservators had been pursuing, and pointing out the reasons that had led to the present necessity for thinning. The party were then conducted to Lord's Bushes, which, as an example of the beautifying effect of judicious thinning, is almost unrivalled, this district having been submitted to the operation repcatedly since the Forest was taken over by the present Conservators. After tea at the Royal Forest Hotel, Chingford, a meeting of the Club was held, Mr. F. Chancellor, the President, in the chair. The discussion was opened by Prof. Meldola, who commenced by explaining that the statements which had been inserted in the newspapers respecting the attitude taken by the Club in the present controversy had been made without authority, and were devoid of foundation. He then went on to show that the observations made by him in $188_{3}$ in connection with the agitation against the railway scheme with which the Forest had then been threatened (see the article quoted in our columns in last week's note), had recently been applied to the present thinning operations without his concurrence, and in direct opposition to the views which he had formed after five visits to the districts now being dealt with, and after an intimate acquaintance with the Forest for a period of more than twenty years. Having explained the general grounds on which he based his opinions, he stated that in his belief the Forest as a whole showed a marked improvement since it had been under the care of the present management, and he considered that much of the recent criticism had been most unjust, and the newspaper accounts exaggerated to an extent bordering on the ludicrous. Two or three speakers took an adverse position, but Prof. Boulger, Mr. Howard, Mr. F. C. Gould, Mr. W. Crouch, the President, Mr. William Cole, and others who knew the Forest well, expressed general approval of the recent operations. Mr. Angus Webster, the Duke of Bedford's forester, who accompanied the party, was of course obliged to reserve his opinion owing to his official connection with the committee of experts appointed by the Corporation, the report of this committee not having as yet been presented. As the outcome of the discussion, it may safely be said that the public will not be so ready in future to give credence to the opinions of irresponsible and inexperienced scribblers who, often with the best of motives, may seriously hamper the work of the Conservators in their endeavour to restore the Forest to a more natural condition in those parts which have for so many centuries been made unnatural and unsightly by the existence of the rights of lopping. Although it had not been the original intention of the officers and conductors to allow a formal motion to be put, a strong desire was expressed that this should be done, and on 
taking a vote a large majority decided that some resolution should be framed. Not the least important feature of the meeting were the speeches made by Sir Frederick Young (formerly chairman of the "Forest Fund"), and others who had taken up an antagonistic attitude in the correspondence. Having visited the place and heard the explanations given on the ground, these gentlemen admitted that as the result of the afternoon's inspection they had seen good reason for modifying their views, and they finally voted for the following resolution, mored by Prof. Boulger and seconded by the Rev. IV. C. Howell, of Tottenham :- "That in the opinion of this meeting the general action of the Conservators in the recent thinnings has been judicious." Forty-one voted in favour of this resolution, and eight against. The views of those whose opinions should count for much in reassuring the public that no alarm need be felt as to the future of the Forest, have thus been expressed in very decided terms.

\section{THE UNIVERSITY OF LONDON.}

A GENERAL meeting of the Association for Promoting a Professorial University for London, was held in the rooms of the Chemical Society, Burlington House, on Saturday, April $2 S$; the Right Hon. T. H. Huxley was in the chair.

The committee reported that having carefully studied the report of the Gresham . Commission, they considered it is generally in accord with the principles of the Association.

In accordance with this report a resolution, moved by Prof. Rücker, and seconded by Prof. Ramsay, was unanimously carried, expressing general approval of the scheme. The committee were also empowered to draw up a memorial to the Government, to be signed by members of the Association, and others who may agree with it, urging the Government to appoint a Statutory Commission to establish a Teaching. University in London on the basis of the scheme of the Royal Commission.

This action on the part of the Association is, we hope, another step towards the realisation of the scheme of the "Gresham Commission."

It was at one time to be feared that it would be impossible to reconcile the various divergent views which had been expressed as to the best constitution for the University. Now, however, that the Colleges of Physicians and Surgeons, the Governing Body and Senate of University College, and the Professorial Association, have all expressed a general approval of the scheme, while the London County Council finds in it nothing inconsistent with its own views, it is evident that the Commissioners have achieved a remarkable success. The University of London has not yet spoken, but the oppo. nents of the scheme in Convocation were unable to carry their resolutions, and it is to be hoped that the University may yet be saved from the discredit of blocking the way.

\section{NOTES}

A STATUE of Durand-Claye, the pioneer of the system for the agricultural utilisation of sewage, was unveiled at Gennevilliers, on Friday last. The funds for the erection of this monument were raised by international subscription, in accordance with a proposal made at the Congress of Hygiene held in Paris in 1889.

WE regret to announce the death, at Geneva, of the eminent chemist; J. C. Galissard de Marignac. We have also to record the death of Laureano Calderon, Professor of Biological Chemistry in Miadrid University.

THE Kazan Society of Naturalists will celebrate the twenty-fifth anniversary of its foundation on May 25 , by a general meeting of members, at which a statement will be read of the works published by the Society during its existence.
The Times says that the Attorney-General has given his sanction to the sum of $f 25, c 00$, the residue of the legacy of the late Mr. Richard Berridge, being given, in trust, to the British Institute of Preventive Mledicine, for the endowment of a laboratory devoted to the bacteriological and chemical examina. tion of the water supply, with special reference to the best means of preventing the conveyance of disease through water. A large laboratory is now in course of erection for the purpose on the site secured by the institute at Chelsea.

Earthouakes continue to be felt in Greece. A severe dis. turbance, having its centre in Atalanti, occurred on Friday, April 27 (see p. 7), and the Times correspondent says that the inroads of the sea in this district have extended inland for a distance of three kilometres. The surface of the sea in many places is coloured with the products of submarine eruptions. A chasm has opened in the ground not far from Atalanti, and extends in a south-westerly direction for about twelve kilometres.

At the anniversary meeting of the Zoological Society, held on Monday, Sir William H. Flower, K.C.B., F.R.S., was reelected President, Mr. C. Drummond, Treasurer, and Dr. P. L. Sclater, F.R.S., Secretary to the Society for the ensuing year. The following were elected into the Council, in the place of retiring members:--Dr. John Anderson, F.R.S., Mr. Herbert Druce, Sir Joseph Fayrer, F.R.S., Major Henry P. St. John Mildmay, and Prof. A. Newton, F.R.S.

THE opening meeting of the British Association this year will take place on Wednesday, August $S$, when Prof. Burdon Sanderson, F.R.S., will resign the chair, and the Marquis of Salisbury will assume the presidency and deliver an address. On Thursday, August 9, a soirée will be held. On August 10, a discourse will be delivered by Dr. IV. H. IVhite, C.B., F.R.S., on "Steam Navigation at High Speeds"; on August 13, Prof. J. S. Nicholson will lecture on "Historical Progress and Ideal Socialism"; on August 14 there will be another soirce, and the concluding meeting will be held on Wednesday, August 15 .

THE committee for the establishment of a station at Cumbræ, for the study of marine zoology and botany, are making good progress with their arrangements. The $A r k$ has now been put into order for the summer months, and the services of an ex. perienced keeper secured. Mr. David Robertson, the well-known "naturalist of Cumbrre," takes a warm interest in the scheme, and is giving it his personal supervision. A number of students have intimated their intention of availing themselves of the facilities for research thus provided. $A$ con siderable sum has been subscribed for the erection of a permanent building, and also for the annual expenses of the station-about half of what is required in each case; and the committee have good hopes that the remaining half will soon be obtained.

THE Geologists' Association have arranged an excursion to Oxted and Titsey for Saturday next, under the direction of $\mathrm{M} r$. G. Leveson Grower and Mr. W. Topley, F.R.S. The district is not only interesting geologically, but contains a number of archæological remains. During IVhitsuntide a long excursion has been arranged to Cambridge and Ely, and on May $26 \mathrm{Mr}$. John Hopkinson and Mrr. Worthington G. Smith will conduct a party to Luton, Caddington, and Dunstable. In the neighbourhood of Caddington are numerous pits in Drift (brick-earth, \&c.), and Tertiary remanié beds, worked for clay and sand for brick-making, and for gravel. In these pits Mr. Smith discovered an old Palrolithic land-surface on Tertiary remanié, surmounted by re-laid Tertiary clay, and contorted, implementiferous red plateau drift. On this Palæolithic floor flint flakes of all kinds occur in hundreds, nearly all as keenedged as knives. That these fakes were made on the spot is

No. I 279 , VOL. 50] 